\title{
O discurso poético de Rui Knopfli em uma relação interdiscursiva
}

Paula Terra Nassr ${ }^{1}$

\begin{abstract}
Resumen: Este artículo presenta un análisis del discurso poético del escritor mozambicano Rui Knopfli, basado en los estudios del Análisis del Discurso que están apoyados en presupuestos filosóficos, materialistas históricos y dialécticos. Las relacciones de significación y de interdiscursividad entre el discurso del poeta africano y de poetas brasileños van a desvelar la condición de que el lenguaje pasa siempre por un proceso en que la histórica, los sujetos y los sentidos están envueltos a la ideologia, de modo que, los movimientos de significación no presentan un carácter de ociosidad
\end{abstract}

Palabras Clave: Rui Knopfli; Discurso Poético; Análisis de Discurso; Procesos de significación; Interdiscursividad.

Resumo: Este artigo apresenta uma análise do discurso poético do escritor moçambicano Rui Knopfli, com base nos estudos da Análise do Discurso que estão alicerçados em pressupostos filosóficos, materialistas históricos e dialéticos. As relações de significação e de interdiscursividade entre o discurso do poeta africano e de poetas brasileiros vão desvelar a condição de que a linguagem passa sempre por um processo em que a histórica, os sujeitos e os sentidos estão envoltos à ideologia, de modo que, os movimentos de significação não apresentam um caráter de ociosidade.

Palavras-Chave: Rui Knopfli; Discurso Poético; Análise do Discurso; Processos de Significação; Interdiscursividade.

\section{Introdução}

Se pensarmos os estudos da linguagem priorizando a forma e a estrutura da língua, iremos nos filiar a linhas de pesquisa que pensam a língua como um objeto estático, como um sistema onde não há possibilidades para equívocos, deslizamentos de sentido, ambiguidades e contradições, visto que podem desestabilizar a ordem da língua como objeto de estudo de uma ciência mais objetiva. Porém, aqueles que trabalham com a linguagem de modo a romper paradigmas, binarismos, possibilitando que os sentidos sejam sempre outros, sem haver suas pré-definições, devem filiar-se a uma proposta de reflexão sobre a linguagem em que o sujeito, a história e a ideologia sejam cúmplices no jogo dos sentidos. Jogo este, em que sujeito e sentido se constituem num continuum, num constante vir a ser.

Nos anos 60, na França, Michel Pêcheux, com suas inovadoras ideias, vem estabelecer novos paradigmas a estudos já defasados sobre as ciências da linguagem. Das suas observações e estudos surge, então, a Análise de Discurso (AD) que passa a ser uma disciplina

1 Professora SMED/POA. Mestre em Teorias do Texto e do Discurso (UFRGS) e doutoranda em Literaturas Luso-africanas (UFRGS). 


\section{Conexão Letras}

que não trabalha com a língua como sendo um sistema abstrato, conforme relata Orlandi (1999), mas como espaço de interação dos sujeitos com o mundo, considerando a produção de sentidos enquanto parte de suas vidas. Não sendo mais um sistema fechado em si, a língua passa a ser relacionada à sua exterioridade, levando-se em conta no processo de produção da linguagem, o sujeito na sua história e as situações em que este vai produzir o dizer.

Nessa nova proposta, Pêcheux passa a articular conhecimentos do campo das Ciências Sociais e da Linguística. Contudo, de um modo bem particular, faz algumas rupturas em que o político e o simbólico se confrontam, colocando questões para a Linguística, interpelando-a pela historicidade que deixa de lado, da mesma maneira que questiona as Ciências Sociais no que se refere à transparência da linguagem sobre a qual elas se baseiam.

$\mathrm{Na} \mathrm{AD}$, não há um sentido literal, este não está pré-fixado, ao passo que, não pode ser qualquer um, pois há uma determinação histórica. Para se compreender o funcionamento do discurso, Orlandi (1998) explica que é preciso fazer intervir a relação com a exterioridade, ou seja, compreendermos a sua historicidade, pois o repetível em nível do discurso é histórico e não formal.

Viu-se, então, que na AD o discurso é determinado pela sua exterioridade e ao mesmo tempo vai remeter a outro discurso, isso tem a ver com a memória do dizer (interdiscurso), espaço em que os sentidos são sempre referidos a outros sentidos e é daí que surgem suas identidades. Como observa Orlandi (1998) o processo de interpretação é regido por condições de produção específicas, que aparecem como sendo universais e eternas, pois vai ser a ideologia que irá produzir esse efeito de evidência e unidade, sustentando sobre o já dito os sentidos institucionalizados, admitidos como "naturais". É pela ideologia que se naturaliza o que é produzido pela história, ela vai guiar a interpretação dos sentidos em uma certa direção e esta será determinada pela relação da linguagem com a história em seus mecanismos imaginários. A ideologia vai fazer parte dessa relação da linguagem com o mundo, de modo que, linguagem e mundo se refletem, no sentido da refração, do efeito imaginário de um sobre o outro. Há uma contradição entre mundo e linguagem, e a ideologia é o trabalho desta contradição. Portanto, é importante entendermos essas relações citadas anteriormente para que possamos distinguir a forma abstrata, que é transparente e literal, da forma material, que é histórica e que está sujeita a equívocos e opacidades.

Há de se salientar, ainda, que quando se pensa a determinação histórica dos sentidos nos processos discursivos, não se está pensando a história como evolução e cronologia, mas o que interessa são as maneiras como os sentidos são produzidos e vão circular. Nos estudos sobre a linguagem, muitos são os processos que trabalham com a questão dos sentidos (sinonímia, paráfrase, polissemia, paródia, entre outros), todavia, o que devemos observar é como as noções de sentido e de linguagem vão aparecer nesses diferentes processos. E, principalmente, neste artigo, como os estudos da Análise do Discurso alicerçados em pressupostos filosóficos, materialistas históricos e dialéticos vão contribuir para as análises poéticas realizadas.

\section{Concepções em torno da paráfrase}

Se formos tratar a linguagem e o sentido de modo mais estrutural, os processos que envolvem significação passam a representar relações de equivalência entre palavras, frases, enunciados, tornando a comunicação algo estável e com uma ideia de que possa ser previsível. Affonso Romano Sant'anna (2008) vai tratar da paráfrase como sendo um processo mais voltado à ideia da imitação e da cópia e se, em geral, a história é a história 
da diferença e do acréscimo, não irá combinar com a repetição. Ainda, consoante o autor (2008), a paráfrase repousando sobre o idêntico e o semelhante, pouco faz a linguagem evoluir, permanecendo oculta em algo estabelecido, em um velho paradigma. Todavia, se pensarmos a paráfrase relacionada aos estudos da $\mathrm{AD}$, não poderemos prescindir das relações históricas e sócio-políticas que atravessam as palavras, os textos, os discursos, observando as ideologias que transitam. $\mathrm{O}$ autor trabalha a paráfrase em oposição à paródia, para a AD não há essa ideia de oposição. Sant'anna pensa a paródia repousando sobre novos paradigmas e a paráfrase sobre velhos, entretanto desde o ponto de vista da AD há uma relação tensa na paráfrase que busca manter paradigmas e que não se isenta de reformular esses paradigmas. Na paródia vai se instaurar um processo de contra-identificação, onde os saberes de uma mesma formação discursiva (FD) se tornam contraditórios e estranhos entre si. A paródia busca subverter os sentidos já cristalizados que circulam a partir da Ideologia Dominante, de modo a romper com a manutenção dos discursos que se instauram pela refração dialética, assim ela desopacifica as reproduções.

Importante esclarecer que tanto a paráfrase quanto a paródia não vão apresentar um caráter ocioso, enquanto Sant'anna aproxima a paráfrase da sinonímia não se dá conta de que as relações de sinonímia dependem de acontecimentos e das formas como os sujeitos se reconhecem em uma determinada FD.

A formação discursiva² é o lugar da constituição do sentido, conforme Pêcheux (1988). Ele explica que as palavras mudam de sentido ao passarem de uma FD a outra. Assim, não são somente as intenções do sujeito que determinam o dizer, existe uma ligação entre a intenção individual e um pacto social. A noção de sentido está intrinsecamente ligada às condições de produção do discurso e à relação de paráfrase entre sequências que formam famílias parafrásticas (famílias de sentido). Para poder entender o processo parafrástico deve-se entender a forma-sujeito de modo a não prescindir da língua relacionada à história e do sentido à contradição, pois se as palavras ficam sem a história a língua fica só na etimologia e ao se inscreverem no interior de uma dada FD elas adquirem sentidos contraditórios. A paráfrase é um processo orgânico porque movimenta saberes de FDs diferentes, possibilitando sempre reformulações.

Retomando Pêcheux - 1975 - (1988), no que concerne ao sentido, ele diz que uma palavra, proposição ou expressão, não tem um sentido particular (sentido literal). E se não existe um sentido literal, não existe fonte da qual possa derivar sentidos por meio de uma lógica linguística combinatória. Para o autor, se realmente houvesse uma literalidade, as palavras não poderiam receber os diversos sentidos que recebem, em conformidade com uma ou outra FD. Pois dentro da mesma FD os sentidos parecem igualmente evidentes.

O que vai realmente determinar o sentido das palavras são as posições ideológicas que estão em jogo no processo sócio-histórico em que são (re)produzidas. Dessa maneira, então, as palavras mudam de sentido de acordo com as posições dos sujeitos que as utilizam, obtêm seu sentido em consonância com essas posições, isto é, em referência às formações ideológicas. ${ }^{3}$

2 A noção de FD surgiu das ideias de Foucault sobre o discurso. Para ele as regras de formação do discurso são condições de existência - mais também de coexistência, de manutenção, de modificação e de desaparecimento - em uma repartição discursiva dada. Essas regras de formação permitem a determinação dos elementos que compõem o discurso e determinam uma FD. (FOUCAULT, 2000, p. 43)

3 Para Pechêux e Fuchs - 1975 - (1993, p. 166), a Formação Ideológica (FI) constitui-se num elemento capaz de intervir, como uma força que se opõe a outras forças, na conjuntura ideológica característica de uma formação social, em um momento específico. Assim, cada FI se constitui num conjunto complexo de atitudes e representações que não são individuais nem universais, mas que se relacionam mais ou menos diretamente a posições de classes em conflito umas com as outras. 
A ideologia vai designar o que é e o que deve ser o significado de uma palavra, através do hábito e do uso, muitas vezes, por desvios que são linguisticamente marcados. Por isso, é ela que fornece as evidências através das quais "todo mundo sabe" o que as palavras significam. Essas evidências fazem com que as palavras aparentem dizer o que realmente dizem em uma dada FD, originando, portanto, uma ilusão de "transparência da linguagem".

A falsa transparência disfarça o caráter material do sentido das palavras; este refere à dependência do que Pêcheux (1988, p. 159) designa de [...] "todo complexo das formações ideológicas". Dentro dos estudos da $\mathrm{AD}$, há uma certa manutenção do sentido, da paráfrase (matriz do sentido), porém há o surgimento do novo sentido, fonte do sentido (polissemia).

Dessa forma, ao produzir seu discurso, o sujeito produz sentidos e passa pelos processos parafrásticos, que são relacionados com o dizível, a memória e pelos polissêmicos, que são relacionados com a ruptura de processos de significação.

Pêcheux -1969 - (1993) nos primeiros tempos da AD via a paráfrase como a possibilidade de substituição de segmentos discursivos em um contexto. Essas substituições eram índices de equivalência, isto é, sequências de um domínio semântico que constituíam formas semânticas equivalentes de uma mesma proposição. Sendo assim, a substituição de elementos em um determinado contexto discursivo estabelecia uma relação de sinonímia entre esses elementos.

Essa noção de paráfrase sofre ainda influência da linguística distribucional de Harris e, de acordo com Courtine (1981), esse modo de considerar o fenômeno tem como resultado a construção de classes de equivalência distribucionais, interpretadas como classes de paráfrase discursiva. Essas classes de equivalência manifestam a presença de invariantes recorrentes em um conjunto de sequências, bem como a presença de classes de comutação de outros elementos, em que as formas de invariança, estáveis e idênticas, constituem o contexto distribucional. Ocorre, então, uma variação regular da ordem da repetição, ou seja, da ordem do pré-construído como repetição do mesmo, como reiteração do idêntico, em um espaço em que repetição e reprodução mesclam-se.

Em vista disso, é que para Courtine (1981) as classes de paráfrase discursiva, nos primórdios da $\mathrm{AD}$, são resultado de uma série de homogeneizações que acabam por colocar o discurso na categoria do mesmo.

Pêcheux juntamente com Fuchs -1975 - (1993) repensa suas ideias anteriores e percebe que as relações de substituição que constituíam a paráfrase não podiam ser reduzidas à mera equivalência, o que fez com que ele distinguisse dois tipos de substituição: as simétricas e as orientadas. Na primeira, ocorre que um elemento é, dentro do mesmo contexto, sinônimo do outro. Já no segundo tipo de substituição, os elementos substituíveis não são equivalentes, mas se pode passar de um ao outro.

É importante destacar que o autor (1993) vai associar a noção de paráfrase à produção de sentido, e esta é indissociável da relação de paráfrase entre sequências, em que a família parafrástica constitui a "matriz do sentido".

A paráfrase para Pêcheux, conforme Serrani (1993) salienta, é uma das questões em que se concentra a $\mathrm{AD}$, já que o projeto desta consiste em estabelecer elementos que venham contribuir para os linguistas que têm a preocupação de investigar o suporte linguístico dos processos sócio-históricos.

Baseada nos trabalhos de Pêcheux (1993) e Courtine (1981), Serrani (1993) ${ }^{4}$ desenvolve um estudo sobre a repetição dentro da discursividade, mais enfaticamente, sobre a

4 O trabalho de Serrani está voltado para o funcionamento da paráfrase sob a ótica da Análise do Discurso (AD). 
paráfrase. A paráfrase é vista por ela (SERRANI, 1993, p. 43): [... "como uma relação semântica não-estável, que vem em decorrência de alguma qualidade, pertencente às frases, que possa ser observada."

A autora pensa que a paráfrase não pode ser concebida como uma relação de validade universal, porque não convém pressupor qualquer acordo pré-determinado entre os protagonistas da linguagem, visto que a produção de sentidos no discurso é o lugar de mal-entendidos, equívocos, disputa.

Serrani vai adotar um posicionamento frente a essa questão, que pressupõe uma percepção do fenômeno de uma forma não binária, distinta da que vê, exclusivamente, que duas frases podem ser ou não paráfrases. ${ }^{5}$ Ou seja, para ela vale a ideia de que os sentidos são sócio-historicamente determinados e devem ser referidos às suas condições de produção. Assim, é isso que vai permitir identificar uma relação parafrástica entre enunciados, que não se atendo às relações de substituição, não podem ser paráfrases um do outro.

Ainda para a autora (1993, p. 47), a paráfrase pode dar a ideia de "ressonância de significação", isto é, essa ressonância é compreendida como um efeito de vibração semântica mútua entre formações discursivas contraditórias ou até mesmo antagônicas. Essa noção de ressonância, de acordo com a autora, permite incluir o sujeito na concepção de paráfrase, já que ela sempre ressoa para alguém, seja na dimensão dos interlocutores empíricos projetados no discurso (projeção que é importante para o domínio das formações imaginárias), seja na dimensão do sujeito.

A ressonância interdiscursiva, segundo Serrani, permite trabalhar com uma noção de linguagem heterogênea, pois para definir como as unidades envolvidas ressoam é necessário colocar em jogo outros discursos, como espaços virtuais de leitura da sequência descrita. Enfim, vistas por esse ângulo, as paráfrases [...] "ressoam significativamente na verticalidade do discurso e concretizam-se na horizontalidade da cadeia, através de diferentes realizações lingüísticas" (SERRANI, 1993, p. 47).

Orlandi (1999) trabalha com a noção de paráfrase, porém diferentemente dos demais, pois a opõe à noção de polissemia. A autora apresenta essas noções como sendo duas forças que trabalham continuamente o dizer, de tal modo que todo discurso se faz nessa tensão: entre o mesmo e o diferente ${ }^{6}$. Ao tomar a palavra o sujeito produz uma mexida na rede de filiação dos sentidos, porém fala com palavras já ditas. E é nesse jogo entre a paráfrase e a polissemia, entre o já dito e o a se dizer, que os sujeitos e os sentidos se movimentam para se (re)significar.

A autora (1999) trata também de outros dois processos que envolvem a paráfrase e a polissemia - a produtividade e a criatividade. A criação em sua dimensão técnica é produtividade, reiteração de processos já cristalizados. Esta é orientada pelo processo parafrástico, a produtividade faz o homem retornar sempre ao mesmo espaço dizível, produzindo a variedade do mesmo. Por outro lado, a criatividade implica a ruptura do processo de produção da linguagem, pelo deslocamento das regras, produzindo movimentos que afetam os sujeitos e os sentidos na relação com a história e com a língua. Desse modo, surge o diferente, aparecem novos sentidos.

5 A concepção binarizante de paráfrase é a que predomina nos estudos puramente linguísticos, em que há substituições sinonímicas, onde consideram que as expressões possuem o mesmo sentido. (Maria colocou a mesa em outro lugar. / Maria botou a mesa em outro lugar.).

6 Orlandi (1990, p. 43) acrescenta que não somente existe a tensão entre esses dois processos (paráfrase/polissemia), mas que há também uma con-fusão entre eles. São confusos, visto que, obscuros e transparentes, misturados ou combinados, difusos ou dispersos. O mesmo e o diferente às vezes não são passíveis de serem distinguidos no discurso. 
A paráfrase, segundo Orlandi (1999, p.38), “é a matriz do sentido, já que não há sentido sem repetição, sem sustentação no saber discursivo, e a polissemia é a fonte da linguagem, uma vez que ela é a própria condição de existência dos discursos". Pois, se os sentidos e os sujeitos não fossem múltiplos, não pudessem variar e serem outros, não haveria necessidade de dizer. A polissemia representa movimentos distintos simultâneos de sentido no mesmo objeto simbólico.

Ao compreender a relação da paráfrase com a polissemia, o analista se propõe observar como o político e o linguístico vão se relacionar um com o outro na constituição dos sujeitos e na produção dos sentidos, que são marcados ideologicamente.

Se pensarmos os processos discursivos acordando com a ideias de Bakhtin, temos que levar em conta que a discursividade está fundada na relação com o outro, todo dizer é uma resposta ao dizer do outro.

Em Marxismo e Filosofia da Linguagem, Bakhtin e Volochinov (1992) explicam que é por meio da palavra que me defino em relação ao outro, assim como à coletividade. Daí decorre a famosa metáfora empregada pelos teóricos, em que a palavra serve como uma ponte lançada entre mim e o outro, recaindo sobre as extremidades de cada um destes o suporte, o apoio de tal ponte. Conforme os autores (1992, p.66) "a palavra torna-se uma arena em miniatura, na qual valores sociais de diferentes orientações ideológicas se entrecruzam, lutam".

Ainda, conforme os autores (1997, p.177), “o enunciado está repleto de ecos e lembranças de outros enunciados", aos quais está vinculado no interior de uma esfera comum da comunicação verbal, dessa maneira, deve ser considerado como uma resposta a enunciados anteriores.

Vista por esse viés marxista, a discursividade é, nos estudos bakhtinianos, um processo que se apresenta sempre relacionada ao dialogismo, em que o eu vai relacionar-se sempre com um tu (coletivo), que não é necessariamente empírico e que constitui o eu pela história.

Nesses movimentos relacionais dos processos discursivos, a memória discursiva sustenta o dizer em uma estratificação de formulações já feitas, segundo nos explica Orlandi (1999), porém estas são esquecidas e vão construindo uma história dos sentidos. Os sentidos são construídos com base nessa memória na qual os sujeitos não detêm o controle, dando a impressão de que sabem do que estão falando. Por causa disso, se forma uma ilusão de que são a origem do que dizem. Mas esse apagamento é necessário para que os sujeitos se filiem a um lugar possível no movimento da identidade e dos sentidos. Estes não apenas retornam, eles se projetam em outros sentidos, constituindo outras formas de subjetivação dos sujeitos.

Os sentidos vão resultar então de relações em que um discurso aponta para outros que os sustentam, assim como para dizeres futuros, sempre num movimento de continuidade, não havendo como nos reforça Orlandi (1999, p.39) "um começo absoluto nem um ponto final para o discurso". A autora ainda complementa, em consonância com os estudos bakhtinianos, que um dizer tem relação com outros dizeres realizados, imaginados ou possíveis.

Ao observar os discursos o analista deve analisar as condições de produção destes. Orlandi (1999) diz que as Condições de Produção (CP) compreendem fundamentalmente os sujeitos e a situação; e que também a memória faz parte da produção do discurso. Considerando-se as $\mathrm{CP}$ em sentido estrito (circunstâncias da enunciação) tem-se o contexto imediato. E ao considerar em sentido amplo, incluem-se o contexto sócio-histórico e ideológico.

Os sujeitos envolvidos nesse processo de produção a ser analisado são o poeta Rui Knopfli e os escritores com os quais dialoga. O espaço da memória que os une tem a ver com o espaço do discurso colonialista, visto que tanto a África (espaço do poeta moçambicano) quanto o Brasil (espaço dos demais poetas), foram colonizados por portugueses. 
A seguir, uma análise de um discurso poético mergulhado em um contexto em que o discurso colonial se torna uma ponte entre África e Brasil.

3 Relações interdiscursivas: poesia e sentidos em torno do social

Pelos anos 40, os escritores brasileiros são lidos com grande intensidade e entusiasmo por escritores africanos nos territórios ocupados por Portugal, conforme relata Chaves (2006, p.34) e eles vão alimentar com a literatura brasileira um vivo processo de interlocução, visto que estão em projetos de construção da identidade nacional. Percebiam nos textos brasileiros um meio de buscar elementos para reflexão de novas formas de ver o mundo. Eles ainda estavam no processo de lutas pela libertação do jugo colonialista, que cessou em 1975, porém para eles o Brasil refletia uma situação desejosa, já que desde o final do século XIX era considerado um país "livre" da colonização. E este desejo de liberdade e de identidade nacional é que unia as culturas separadas pelo oceano. Nesse processo de associação de culturas via discurso literário, os africanos iam compondo retratos idealizados do Brasil, que se firmavam como um apoio, como um modelo a ser seguido.

O poeta Rui Knopfli não foge desse cenário, era leitor de vários escritores brasileiros e, a partir de suas leituras, desenvolve um discurso poético em que Carlos Drummond de Andrade, Manuel Bandeira, Vinícius de Moraes, entre outros, são seus interlocutores dentro de um discurso poético ansioso por firmar-se em um lugar, em um espaço de identificação e de luta contra o silenciamento advindo do contexto traumático do período colonial e de guerras pela libertação.

Nos poemas a seguir veremos como os sentidos que circulam vão apresentar processos de significação que ora podem apresentar uma identificação ora podem mostrar um deslocamento ou até ruptura com as ideias com as quais dialoga.

\begin{abstract}
Contrição
Meus versos já tem o seu detractor sistemático:/ uma misoginia desocupada entretém os ócios/ compridos, meticulosamente debruçada sobre / a letra indecisa de meus versos. / em vigília atenta cruza o périplo das noites/ de olhos perdidos na brancura manchada do papel, progredindo com infalivel pontaria/ na pista das palavras e seus modelos./ Aqui se detesta Manuel Bandeira e além/Carlos Drumond de Andrade também/ Brasileiro. Esta palavra vida/foi roubada a Manuel da Fonseca/ (ou foi o russo Vladimir Maiacovsky/ quem a gritou primeiro?). Esta,/ cardo, é Torga indubitável, e/ se Deus Omnipresente se pressente,/ num verso só que seja, é um Deus/ em segunda trindade, colhido no Régio/ dos anos trinta. Se me permito uma blague,/ provável é que a tenha decalcado em O'Neill/ (Alexandre), ou até num Brecht/mais longínquo. Aquele repicar de sinos/ pelo Natal é de novo Bandeira (Porque não/ Augusto Gil,/ António Nobre, João/ De Deus?). Estão-me interditas,/ como certos ritmos, certas palavras. Assim, / não devo dizer flor nem fruto, / tão-pouco utilizar este ou aquele nome próprio,/ e ainda certas formas da linguagem comum,/ desde o adeus português (surrealista)/ ao obrigatório bom dia! (neo-realista)./ Escrevendo-os quantos poetas sem os saber,/ mo interditavam apenas a mim; a mim, perplexo/ e interrogativo, perguntando-me, desolado:/ - E agora, José?, isto é, - E agora, Rui?/ Felizmente, é pouco lido o detractor de meus versos, senão saberia que também furto em Vinícius, Eliot, Robert Lowell, Wilfred Owen/ (...)/ Que, em suma, roubando aos ricos para dar a este pobre, sou o Robin Hood dos Parnasos e das Pasárgadas (...) (KNOPFLI, 2003, p. 210).
\end{abstract}

O poeta apresenta no poema Contrição ${ }^{7}$, alguns escritores nos quais buscou inspiração para os seus versos, contudo desenha esta apresentação em um leve tom irônico, visto

7 Poema publicado no livro Mangas Verdes Com Sal, em 1969, em Lourenço Marques, no auge das guerras de libertação. 


\title{
Conexão Letras
}

que a ironia, de acordo com Brait (1996), é uma construção discursiva em que existe a presença de um significante recobrindo dois significados, e, portanto, pode assumir entre outros sentidos, o de crítica. O vocabulário empregado denota claramente esta criticidade irônica: "Meus versos já têm o seu detractor sistemático"; "roubando aos ricos para dar a este pobre". Nesse recurso discursivo em que substitui a ideia de inspiração por furtar, subtrair e roubar dos ricos a palavra interdita para seu uso próprio, o coloca em um lugar social de quem, mesmo estando à margem, tem o direito de defesa da sua já tão ciciada voz. Como não existe discurso sem o entrelaçamento de outros, para instaurar o seu dizer, o sujeito busca nessa "misoginia desocupada" a fissura por onde seu discurso poderá ecoar. E o ato de escrever poemas, que é o seu labor primordial dentro do intento de fazer-se sujeito de sua história, vai se apresentar como bem descreve Octavio Paz (1993) como um nó de forças contrárias, no qual sua voz e a voz do outro se enlaçam e se confundem. As fronteiras desse entrelaçamento se apagam, e o seu discurso se transforma insensivelmente em algo que o sujeito poético não pode dominar completamente. O seu "eu" cede lugar a um pronome sem denominação, que tampouco é um tu ou um ele, mas é o espaço do entremeio (entre-lugar), em suma, o espaço da inspiração criadora, da revelação imagética e da emergência de uma consciência social.

Os poemas que seguem vão apresentar uma vez mais este espaço de delito, em que o autor ousa furtar discursos e versos alheios, como forma de montar um caleidoscópio discursivo em que possíveis matizes dão o tom à sua obra poética.

\begin{abstract}
Terra de Manuel Bandeira
Também eu quisera ir-me embora/ pra Pasárgada,/ também eu quisera libertar-me/ e viver essa vida gostosa/ que se vive lá em Pasárgada/ (E como seria bom, Manuel Bandeira, fugir duma vez pra Pasárgada!)./ Entanto tudo me prende aqui/ a este lugar desta cidade provinciana./ Como deixar ao abandono o olhar/ Luminoso dessa mulher que eu amo?/ Quem responderá às inquietas/ Perguntas de minha filha pequena/ (cabelo curto, olhos de sonho)?/ Quem, no sereno da noite, para as beijar/ com ternura e nos braços acalentar?/ E esta vida, este sítio,/ E estes homens e estes objectos?/ E as coisas que amei e as que esqueci?/ E os meus mortos e as doces recordações, / as conversas de café e os passeios no entardecer fusco da cidade? / E o cinema todos os sábados, segurando/ com força a mão de minha mulher? Eles nem são amigos do rei/ e a entrada lá é limitada./Por isso é que eu não fujo/ duma vez, pra Pasárgada (KNOPFLI, 2003, p. 44).
\end{abstract}

No poema, apresentado acima, Terra de Manuel Bandeira ${ }^{8}$, o poeta se vale de um tom parodístico e dialógico: "E como seria bom, Manuel Bandeira,/fugir duma vez pra Pasárgada!", que vem expressar o seu apego à pátria e à família, "Entanto, tudo me prende aqui/a este lugar (...)/Como deixar ao abandono o olhar/luminoso dessa mulher que amo?/ Quem responderá às inquietas perguntas de minha filha pequena (...)?”. A dialogia, no sentido amplo, é entendida apenas como conversa, depois como nos ensina Orlandi (1990), passa a ser referida como interação e pode ser entendida como confronto. Não há mais solidão possível dentro do campo da linguagem, a relação com o outro pode vir a regular, preencher e explicar a ordem do real, tanto o sujeito como o sentido. Dessa maneira, o poeta dialoga com o outro poeta apresentando sua ideia de poder fugir de um espaço que não lhe convém permanecer, devido às inconveniências histórico-sociais. O outro sujeito

8 Muitas são as releituras e diálogos feitos de escritores africanos a partir do poema Pasárgada de Manuel Bandeira. Na sua maioria convergem com a ideia de Knopfli de que a fuga não é o melhor a ser feito, evidenciando um sujeito africano vinculado à sua terra e às suas origens. 
poético (Bandeira, 1986), que por apresentar circunstâncias melhores "lá sou amigo do rei/terei a mulher que quero na cama que escolherei", encontra no seu espaço imaginário um bom lugar para se refugiar "Vou- me embora pra Pasárgada". Já o sujeito knopfliano, devaneia expressando o desejo de também ir para este espaço imaginário de conforto e regalias, porém as circunstâncias históricas não são as mesmas. "Eles não são amigos do rei/e a entrada lá é limitada./ Por isso é que eu não fujo duma vez, pra Pasárgada.". Curiosa é essa forma de expressão, uma vez que mostra no processo dialógico uma forma de falar de si, de seu lugar e do lugar do outro, instaurando uma etapa de autoconhecimento e de justificação da condição de sujeito deslocado do seu tempo e do seu espaço.

No próximo poema, o autor trabalha em consonância com Drummond que no seu poema No meio do caminho apresenta a metáfora da pedra como um espaço de ruptura e de obstaculização, mas que faz o sujeito refletir sobre a sua condição social, existencial. "No meio do caminho tinha uma pedra/Tinha uma pedra no meio do caminho (...) /Nunca me esquecerei desse acontecimento/Na vida de minhas retinas tão fatigadas." Há entre os poemas uma relação parafrástica em que os sentidos se mantêm no mesmo espaço dizível; em Drummond as retinas fatigadas não deixam de perceber tal obstáculo, tal acontecimento do surgimento da pedra, que abala a estabilidade e, em Knopfli, o sujeito se torna alguém diferente, justamente por segurar a pedra, por enfrentá-la, mesmo deixando levar-se pelos sentimentos tão contrários como o amor e a raiva. Em ambos, a pedra simboliza um obstáculo que não passa despercebido, que torna esses sujeitos diferentes, que os faz ressignificar a própria ordem do real e se ressignificarem ao mesmo tempo.

\begin{abstract}
A Pedra no Caminho
Toma essa pedra em tua mão,/ toma esse poliedro imperfeito,/ duro e poeirento. Aperta em/ tua mão esse objecto frio,/ redondo aqui, acolá acerado./Segura com força esse granito/ bruto. Uma pedra, uma arma/ em tua mão. Uma coisa inócua,/ todavia poderosa, tensa,/ em sua coesão molecular,/em suas linhas irregulares./Ao meio-dia em ponto, na avenida/ ensolarada, tu és um homem/ um pouco diferente. Ao meio-dial na avenida tu és um ho$\mathrm{mem} /$ segurando uma pedra. Segurando-a/com amor e raiva. (KNOPFLI, 2003, p. 155)
\end{abstract}

No poema que segue, o sujeito poético knopfliano apresenta uma poética do mirar em volta, do encantamento com o espaço que sempre desejou estar incluído e nesta relação do espaço externo com o seu espaço interno, rompe com o silenciamento para se auto-examinar numa possibilidade de fuga da realidade tão ríspida que está impregnada do ranço colonialista. O espaço do devaneio é para onde pode encontrar o seu tão desejado lugar. Mas, o sujeito poético drummondiano do poema Josée ,com o qual há uma interlocução não vê no seu entorno um espaço para onde fugir de tantas adversidades "Você marcha José, José para onde?". Sabe-se que historicamente os espaços em que ambos estão inseridos não são espaços de acolhimento, são socialmente desestruturados, o do Rui (KNOPFLI, 2003) pela opressão ainda presente do colonialismo e o do José (ANDRADE, 1942) pelos reflexos causados também pela anterior fase colonial, mas que deixou marcas sociais de desigualdades. Os poetas vivem momentos políticos diferentes, mas culturais muito próximos. A colonização portuguesa perpetuou o arquétipo da injustiça no país, o que se pode ver ainda em Moçambique. Embora haja anos de diferença entre a colonização do Brasil e a resistência moçambicana, a poesia desses autores evidencia as máculas da história e

9 Poema escrito durante a Segunda Guerra Mundial e no governo de Getúlio Vargas. Publicado em Poesias. SP: Ed. José Olympio, 1942. 


\title{
Conexão Letras
}

rompe o silêncio da imposição colonial. "E agora, José?/ A festa acabou,/a luz apagou,/o povo sumiu". Ambos podem comover-se, mas os sentimentos e sentidos são contrários, pois se fizéssemos a mesma pergunta para o José, o que será que responderia? E, agora, José não vais reagir, não vais comover-te? Como não sentir-se tomado pela comoção, se "Está sem mulher,/está sem discurso,/está sem carinho, (...)". Então, os sujeitos desses poemas têm em comum o desejo de ver suas pátrias como espaços de bem viver, onde a desigualdade social, que acaba por impedir que muitos Josés sintam a mesma sensação de comoção do Rui, venha a ser algo do passado.

\section{Então, Rui?}

Sobes o barranco, corpo magrote/ e alguns empenos, rosto miúdo,/ nariz agressivo, o olho muito/ agudo,/ ríspido qual ave de presa./ Tua capital a teus pés, / sem que o saiba, longilinea,/alinhada, de carros pequenos/ e brilhantes entre acácias de miniatura./ Coças o peito na zona do esterno/ num jeito muito teu. E olhas./ Teu olhar tem a curvatura/ terna e feroz duma grande-angular./Esse perfil distante de cimento/ e argamassa é toda uma geometria/ decantada e gostosa molhando os quadris/ deleitados no charco doce da baía./ Diacho, que perfil mais bonito, hem?/ Então, Rui, que é isso,/ não vais agora comover-te? (KNOPFLI, 2003, p.207)

No próximo poema, há uma interessante relação parafrástica com o poema de Vinícius de Moraes $\mathrm{O}$ dia da criação ${ }^{10}$.

\begin{abstract}
Nunca mais é Sábado!...
- Conjecturamos à segunda-feira, / início de uma longa ressaca, / em todas as claves, desde o ré menor/gemebundo aos claros tons de sol maior. nós os humildes e os humilhados, / os que não temos rosto próprio porque somos/ o rosto da multidão. Nós, o branco-branco,/ o preto-preto e o branco-preto./ (...), no silêncio húmido dos armazéns, / no bafio burocrático e gris das repartições/ com funcionários de vida atribulada/ funcionários de vida empenhada, / funcionários de vida sempre estragada./ Os que esperam na jaula envidraçada dos cafés,/ fumando o cigarro bronquítico da melancolia;/ na fuligem luminosa do cais, nas zonas/ de carga e descarga, na longa fita de asfalto/ ardente, na perigosa articulação dos ângulos/ de betão do prédio de onze andares./ Os que uma regra de excepção escondeu/ por detrás dos altos muros de um silêncio/ recluso e têm o olhar mortiço/ e a expressão resignada. (...)/ Os que alimentam de miséria a sua miséria/ e outros que, estando melhor, a nutrem/ na miséria de pequenas e grandes indústrias./ E os que nem sequer a alimentam/ no lôbrego ventre de oficinas e fábricas./ Toda a população flutuante do elevador/ e da escada de serviço, do prédio e da rua; (...)/ Da escada de serviço e do elevador/ para o prédio, do prédio para a rua,/ da rua para a praça, da praça para a cidade,/ da cidade para o subúrbio, onde crescem/ a doença, o medo, a fome e o futuro,/-nunca, nunca mais é sábado. (KNOPFLI, 2003, p.213-215)
\end{abstract}

Para Vinícius as coisas vão acontecendo "Porque hoje é sábado" numa também relação dialógica, porém parodística com o sexto dia da criação vinculado ao discurso do catolicismo "Tudo isso porque o Senhor cismou em não descansar no Sexto Dia, e sim no Sétimo". Num tom sarcástico, relata fatos do cotidiano de uma sociedade que sofre, mesmo sendo "protegida" pelo Senhor que tanto idolatram dentro da sua crença católica "Há um divórcio e um violamento/Porque hoje é sábado. (...) Há criancinhas que não comem./ Porque hoje é sábado./Há piquenique de políticos." Tanto no poema de Knoppfli como no

10 Poemas, Sonetos e Baladas. SP: Edições Gavetas, 1946. 
de Vinícius há uma crítica social contundente, em Nunca mais é Sábado, Knopfli inicia já dando continuidade a questão dos dias (sábado e domingo) relacionados no poema com o qual dialoga "- Conjecturamos à segunda-feira, início de uma longa ressaca". Ressaca esta advinda dos dias anteriores, onde não houve o tão esperado descanso, descanso que falta, justamente, por não haver momentos em que os problemas sociais cessam. Depois vem uma listagem também, como no outro poema, de acontecimentos que marcam os pesares de uma sociedade que sofre com as disparidades do seu contexto sócio-político. "Nós os humildes e humilhados, /os que não temos rosto próprio porque somos o rosto da multidão. / (...) Os que alimentam de miséria a sua miséria/e outros que, estando melhor, a nutrem/ na miséria de pequenas e grandes indústrias." No poema de Vinícius o sexto dia (sábado) é o dia da criação, o dia em que tudo deveria dar certo, porém os fatos mostram que não. E no poema de Knopfli, há essa relação parafrástica que apresenta o sábado também como sendo um dia que tudo deveria ser melhor, ser especial, pois não é o "Dia da Criação"? Porém, novamente os fatos que ocorrem com a sociedade não permitem que seja este dia, um dia tão especial, como nos indica o discurso religioso do catolicismo. "Da escada de serviço e do elevador/ para o prédio, do prédio para a rua,/ da rua para a praça, da praça para a cidade,/ da cidade para o subúrbio, onde crescem/ a doença, o medo, a fome e o futuro,-- nunca, nunca mais é sábado."

\section{Considerações finais}

A partir das análises dos poemas, podemos afirmar que os sujeitos e os sentidos, realmente, se ressignificam em cada novo espaço dialógico, em cada movimento de sentido que venha a reforçar a ideia de que não se pode ficar em espaços simbólico e semântico ociosos. Não permanecemos os mesmos no decorrer da história, somos mutáveis a cada interação discursiva, em cada espaço social, em cada formação discursiva na qual estamos inseridos e dentro das quais nos reconhecemos. Knopfli, em seus versos cheios de interação, mostra-nos que mesmo a sua voz estando estrangulada pela engrenagem da contradição histórica, mesmo que, muitas vezes, o dizível não satisfaça, passa a ser ele e ser-se nos outros com os quais mantém a relação dialógica e, no final, o que vale é o sentido, é o sentir-se sujeito do seu discurso, do discurso com o qual se identifica e por meio desse permanecer na história, na sua história: "mas que ecoo inteiro na força do meu grito." (KNOPFLI, 2003, p.46)

\section{Referências}

ANDRADE, C. D. Poesias. São Paulo: Ed. José Olympio, 1942.

BAKHTIN, M. Estética da criação verbal. São Paulo: Martins Fontes, 1997.

BAKHTIN, M.; VOLOCHINOV, V. Marxismo e filosofia da linguagem. São Paulo: Hucitec, 1992.

BANDEIRA, M. Bandeira da vida inteira. Rio de Janeiro: Editora Alumbramento, 1986. BRAIT, B. Ironia em perspectiva polifônica. Campinas: Editora da Unicamp, 1996.

CHAVES, R. A literatura brasileira no imaginário africano: invenção e utopias. In: CHAVES, R.; SECCO, C.; MACÊDO, T. (org). Como se o mar fosse mentira. São Paulo: Editora da UNESP, 2006.

COURTINE, J. J. Analyse du discours politique. Langages, Paris: n. 62,1981. 


\section{Conexão Letras}

FOUCAULT, M. Arqueologia do saber. Rio de Janeiro: Forense Universitária, 2000.

KNOPFLI, R. Obra poética. Lisboa: Editorial da INCM, 2003.

MORAES, V. Poemas, sonetos e baladas. São Paulo: Edições Gavetas, 1946.

ORLANDI, E. P. Terra à vista: discurso do confronto: Velho e Novo Mundo. Campinas: Editora da UNICAMP, 1990.

ORLANDI, E. P. Interpretação: autoria, leitura e efeitos do trabalho simbólico. Petrópolis: Vozes, 1998.

ORLANDI, E. P. A análise de discurso: princípios e procedimentos. Campinas: Pontes, 1999.

PAZ, O. El Arco y La Lira. México: Fondo de Cultura Económica, 1993.

PÊCHEUX, M. - 1975 - Semântica e discurso: uma crítica à afirmação do óbvio. Campinas: Editora da Unicamp, 1988.

PÊCHEUX, M. - 1969 - Análise automática do discurso (AAD-69) In: GADET; HAK (Org.). Por uma análise automática do discurso. Campinas: Editora da UNICAMP, 1993. PÊCHEUX, M; FUCHS, C. - 1975 - A propósito da análise automática do discurso: atualização e perspectivas. In: GADET; HAK (Org.). Por uma análise automática do discurso. Campinas: Editora da UNICAMP, 1993.

SANT'ANNA, A. R. Paródia, paráfrase \& Cia. São Paulo: Editora Ática, 2008.

SERRANI, S. A linguagem na pesquisa sociocultural: um estudo da repetição na discursividade. Campinas: Editora da Unicamp, 1993. 